\title{
Distribution of stable isotopes in surface snow along the route of the 1990 International Trans-Antarctica Expedition
}

\author{
QIN DAHE \\ Lanzhou Institute of Glaciology and Geocryology, Chinese Academy of Sciences, Lanzhou, Gansu 730000, China, and 1990 International \\ Trans-Antarctica Expedition, c/o The International Arctic Project, 413 Wacouta Street, St. Paul, Minnesota 55101, U.S.A.
}

\section{J.R. Petit}

Laboratoire de Glaciologie et Géophysique de l'Environnement, CNRS, 38402 Saint-Martin-d'Hères Cedex, France, and Laboratoire de Modélisation du Climat et de l'Environnement, Division des Sciences de la Matière, CE Saclay, 91191 Cedex, Gif-sur-Yvette, France

J. JOUZEL

Laboratoire de Modélisation du Climat et de l'Environnement, Division des Sciences de la Matière, CE Saclay, 91191 Cedex, Gif-surYvette, France, and Laboratoire de Glaciologie et Géophysique de l'Environnement, CNRS, 38402 Saint-Martin-d'Hères Cedex, France

\section{STIEVENARD}

Laboratoire de Modélisation du Climat et de l'Environnement, Division des Sciences de la Matière, CE Saclay, 91191 Cedex, Gif-surYvette, France

\begin{abstract}
This paper presents the distribution of average $\delta \mathrm{D}$ and $\delta^{18} \mathrm{O}$ values for the top $1 \mathrm{~m}$ of surface snow for a large area of Antarctica. The samples were collected on the 1990 International Trans-Antarctica Expedition which crossed the continent from the northern tip of the Antarctic Peninsula to Mirny Station. The empirical relationships between the isotopes, temperature and elevation are computed. The slopes of $\delta \mathrm{D}$ with respect to the surface temperature for the segments west (Patriot Hills-Vostok) and east of Vostok (Komsomolskaya-Mirny) are not significantly different to that observed between Dumont d'Urville and Dome C (Lorius and Merlivat, 1977) which are often used to interpret deep ice-core isotopic profiles. There is, however, a noticeable shift between the two regression lines with, for a given temperature, higher isotopic values west of Vostok. The deuterium excess values $\left(d=\delta \mathrm{D}-8 \times \delta^{18} \mathrm{O}\right)$ increase sharply at $3000 \mathrm{~m}$ a.s.l. on the plateau, confirming the results of Petit and others (1991).
\end{abstract}

\section{INTRODUCTION}

The interpretation of the deuterium and oxygen-18 composition of the snow layers successively deposited over the Greenland and Antarctic ice sheets provides a very powerful tool for reconstructing climatic changes in polar regions.

These profiles primarily contain information related to temperature as there is, for high-latitude present-day precipitation, a well-obeyed linear relationship between surface temperature and either $\delta \mathrm{D}$ or $\delta^{18} \mathrm{O}$. This approach has been used for more than 20 years, both for Greenland (Dansgaard and others, 1973, 1982) and Antarctic cores (Johnsen and others, 1972; Lorius and others, 1979, 1985; Jouzel and others, 1987b) with records covering various time-scales.

More recently, attention has, in addition, been given to the deuterium excess, $d=\delta \mathrm{D}-8 \delta^{18} \mathrm{O}$ (Craig, 1961 a; Dansgaard, 1964). On a global scale, the annual average value of this parameter is relatively constant with a value around 10 which led Craig (1961a) to define the Meteoric Water line, $\delta \mathrm{D}=8 \delta^{18} \mathrm{O}+10$. However, the deuterium excess in precipitation may vary from season to season, site to site or from glacial to interglacial periods. Such variations contain additional climatic information that cannot be derived from either $\delta \mathrm{D}$ or $\delta^{18} \mathrm{O}$ records alone. In particular, the deuterium excess in precipitation depends on the conditions of humidity and surface temperature that prevailed in the source region of the air mass and on the supersaturation at snow formation (Jouzel and Merlivat, 1984). The deuterium excess in polar snow is now used to derive information about the conditions prevailing in the polar precipitation source regions and their variations in the past (Jouzel and others, 1982; Dansgaard and others, 1989; Johnsen and others, 1989; Petit and others, 1991).

A relatively large variety of isotopic models has now been developed: 
i. Rayleigh models with immediate removal of precipitation (Dansgaard, 1964) or Rayleigh-type models that assume the condensate to be kept partly in the air masses (Merlivat and Jouzel, 1979) apply to the isotopic modeling of precipitation formed from isolated, singlesource air masses.

ii. More dynamically complex models have been developed by Eriksson (1965), Rozanski and others (1982), Fisher and Alt (1985) and Fisher (1990), and the water isotope cycles have now been introduced in two general circulation models (Joussaume and others, 1984; Jouzel and others, 1987a, 1991) that better account for the complexity of the atmospheric processes leading to the formation of precipitation.

These various models are complementary and they allow correct simulation of the main characteristics of isotope distributions $\left(\delta \mathrm{D}, \delta^{18} \mathrm{O}\right.$ and deuterium excess) as observed in present-day precipitation.

Despite such theoretical developments, the interpretation of the isotopic content of ancient precipitation in terms of climatic parameters is still largely based on the observed characteristics of spatial isotopic distributions. For example, isotopic profiles recorded in ice cores are interpreted in terms of temperature records assuming that the temporal isotope/temperature relationship at the site was identical to the observed present-day relationship generally defined on a regional basis (Dansgaard and others, 1973, 1989; Jouzel and others, 1987b).

Moreover, isotopic data in the surface snow come mainly from a few routes that were traversed at different times, and which covered only limited areas. For Antarctica, the most commonly used relationship is that established by Lorius and Merlivat (1977) along a route from Dumont d'Urville Station $\left(66^{\circ} 42^{\prime} \mathrm{S}, 140^{\circ} 00^{\prime} \mathrm{E}\right)$ toward Dome C $\left(74^{\circ} 39^{\prime} \mathrm{S}, 124^{\circ} 10^{\prime} \mathrm{E}\right)$ in Terre Adélie.

Taking into account the vast size of the Antarctic ice sheet and the geographic zonal characteristics of Antarctica it is important to extend considerably the investigation of the distribution of the isotopic ratios in surface snow ( $\delta \mathrm{D}$ and $\delta^{18} \mathrm{O}$ ) so as to provide a better documented data base for interpreting the deep ice-core isotopic profiles and also for validating isotopic model results with respect to present-day data.

\section{SAMPLING ROUTE, BASIC DATA AND RESULTS OF ISOTOPIC MEASUREMENTS}

\subsection{Route, sampling and basic data along the route}

Between 27 July 1989 and 3 March 1990 the 1990 International Trans-Antarctica Expedition succeeded in making a long crossing of the Antarctic continent (Fig. 1). The expedition started from the Seal Nunataks $\left(65^{\circ} 05^{\prime} \mathrm{S}\right.$, $59^{\circ} 35^{\prime} \mathrm{W}$ ) in the northern part of the Larsen Ice Shelf and reached the Antarctic Peninsula after climbing Weyerhaeuser Glacier (the position of the end of the glacier is about $68^{\circ} 45^{\prime} \mathrm{S}, 65^{\circ} 32^{\prime} \mathrm{W}$ ). The crossing of Antarctica was routed along the Peninsula and continued via Siple Station $\left(76^{\circ} \mathrm{S}, 84^{\circ} \mathrm{W}\right)$, the western foot of the Ellsworth Mountains $\left(76^{\circ}-81^{\circ} \mathrm{S}, 87^{\circ} \mathrm{W}\right)$, the Thiel Mountains $\left(85^{\circ} 30^{\prime} \mathrm{S}, 90^{\circ} \mathrm{W}\right)$, and arrived at the South Pole $\left(90^{\circ} \mathrm{S}\right)$

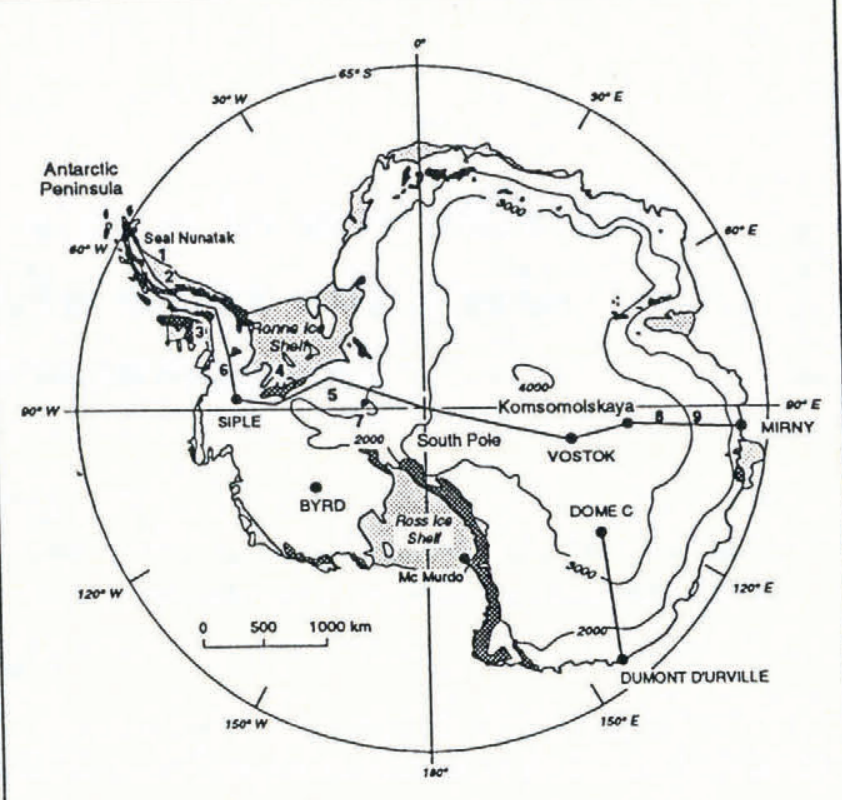

Fig. 1. Map of Antarctica showing the traverse route of the 1990 International Trans-Antarctica Expedition. 1. Larsen Ice Shelf; 2. Weyerhaeuser Glacier; 3. English Coast; 4. Ellsworth Mountains; 5. Patriot Hills; 6. Eights Station; 7. Thiel Mountains; 8. Vostok 1; 9. Pionerskaya.

on 12 December 1989. Then, the expedition continued to Vostok Station' $\left(78^{\circ} 28^{\prime} \mathrm{S}, 106^{\circ} 48^{\prime} \mathrm{E}\right)$ and arrived at Mirny Station $\left(66^{\circ} 33^{\prime} \mathrm{S}, 95^{\circ} 39^{\prime} \mathrm{E}\right)$, via Komsomolskaya $\left(74^{\circ} 05^{\prime} \mathrm{S}, 97^{\circ} 27^{\prime} \mathrm{E}\right)$ and Pionerskaya $\left(69^{\circ} 44^{\prime} \mathrm{S}\right.$, $\left.95^{\circ} 30^{\prime} \mathrm{E}\right)$. The total period was $220 \mathrm{~d}$ and the total distance was $\sim 6000 \mathrm{~km}$.
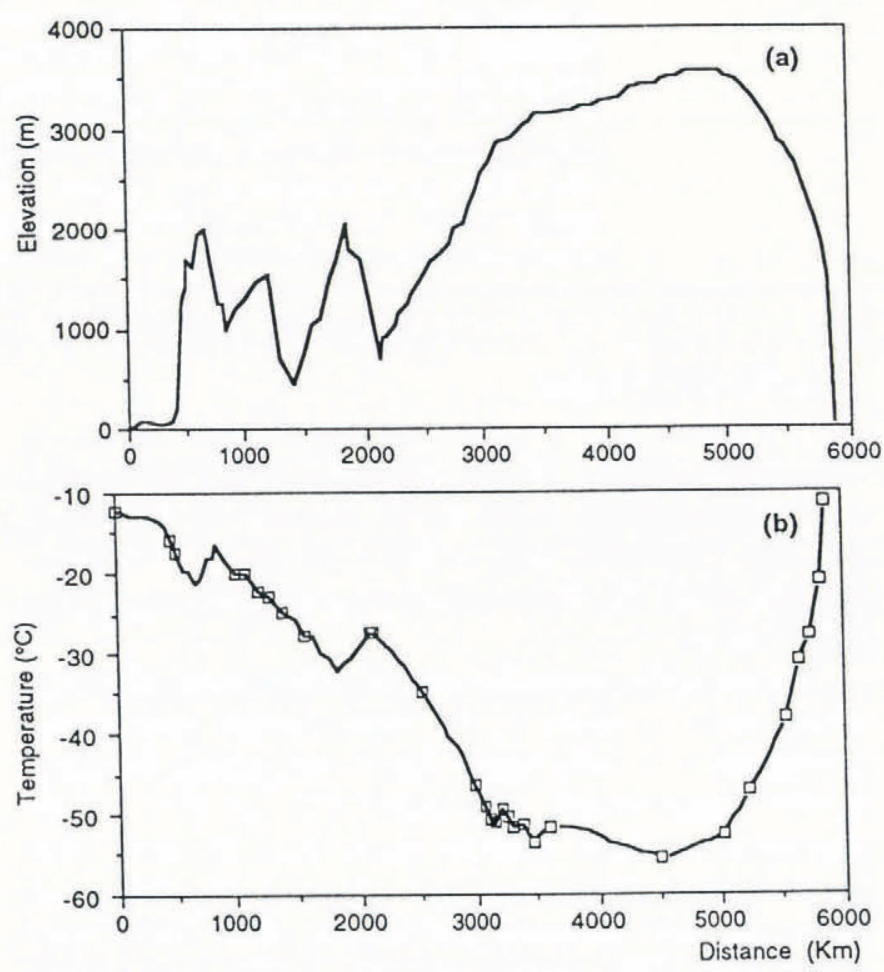

Fig. 2. Elevation (a) and estimated average temperature (b) versus the distance along the traverse route. The open squares in Figure $2 b$ represent the meteorological and/or compiled $10 \mathrm{~m}$ depth temperature. 
Table 1. The classified sources of the collected temperature

$\begin{array}{cccc}\text { Station Meteor- } 10 \mathrm{~m} \text { snow } & \begin{array}{c}\text { Iso- } \\ \text { ological temperature }\end{array} & \begin{array}{c}9.3 \mathrm{~m} \text { snow } \\ \text { thermal } \\ \text { diagram }\end{array} & \text { Source } \\ & \end{array}$

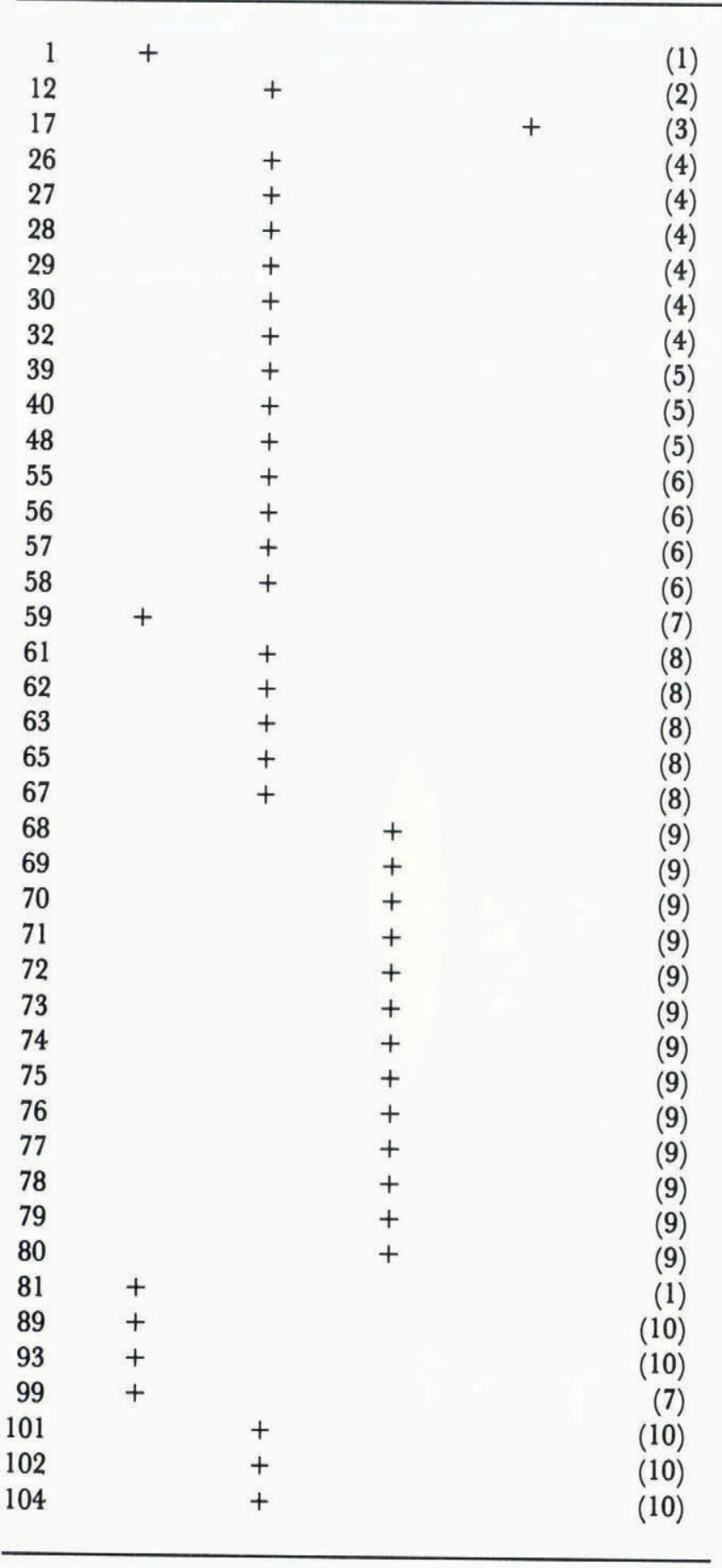

\section{Footnote}

These data come from four different sources: 1. The measured snow temperature. At station $17\left(69^{\circ} 10^{\prime} \mathrm{S}\right.$, $\left.65^{\circ} 18^{\prime} \mathrm{W}\right)$, a dry borehole was drilled using a PICO light auger. A temperature of $-17.3^{\circ} \mathrm{C}$ was measured at $9.3 \mathrm{~m}$ depth in the snow $15 \mathrm{~h}$ after emplacement of the temperature sensor. 2. The meteorological data. There are several meteorological stations on the traverse: South Pole, Vostok, Komsomolskaya and Pionerskaya. Some meteorological stations are very close to our route
For the purpose of isotope determinations, 104 sampling stations were established along the route. Two stations were set up for each degree of latitude or every $\sim 110 \mathrm{~km}$. At each station, a snow pit was excavated to a depth of $1 \mathrm{~m}$ (except for stations 1 to 6 where the depth covered is less than $1 \mathrm{~m}$ ). This is not ideal sampling because a different number of years is represented in each site (Fig. 3) but it was not possible to obtain deeper samples at high-accumulation sites owing to logistics constraints. After a detailed stratigraphic description of each pit (Qin Dahe and Ren Jiawen, 1991), four snow samples were collected, each representing $25 \mathrm{~cm}$. A total of 401 snow samples was collected in polyethylene bottles and kept frozen. The positions of the sampling stations are given in Table 2.

Owing to expedition constraints, we were unable to measure the barometric pressure, snow temperature and snow accumulation. The route distance and the geographic position were accurately recorded daily. Data that were not available from the expedition were obtained from published records.

Because of field conditions, it was not possible to proceed in a straight line, especially in the Antarctic Peninsula and in West Antarctica. It should be noted that from the Seal Nunataks to Patriot Hills the distance to the coast or open water changed very little with increasing distance along the route. In East Antarctica, the route followed practically a straight line.

From the navigational data (personal communication from G. Somers and J.L. Etienne), the locations of the sampling stations were plotted on Drewry's (1982) largescale contour map of Antarctica and site elevations were taken from the map. The elevations of the sampling stations are shown in Figure 2a.

The mean annual surface temperature reported in Table 1 for 42 stations originates mainly from four different data sources. The temperature for the other 62 stations, given in Table 2, was interpolated from existing temperature data, with corrections both for lapse rate and

especially Siple and Eights. We used the published mean annual temperature records at these stations (Schwerdtfeger, 1970). At station 1 , Seal Nunataks $\left(65^{\circ} 05^{\prime} \mathrm{S}\right.$, $59^{\circ} 35^{\prime} \mathrm{W}$ ) there is no temperature record and we therefore adopted the mean annual temperature of $12.1^{\circ} \mathrm{C}$ (Jacka and others, 1984) from Matienzo Station $\left(64^{\circ} 58^{\prime} \mathrm{S}, 60^{\circ} 03^{\prime} \mathrm{W}\right)$. 3. The $10 \mathrm{~m}$ snow temperature. Previous and published works provided such data for or near the sampling stations at $10 \mathrm{~m}$ or deeper (Shimizu, 1964; Taylor, 1965; Lorius and others, 1970; Peel and Clausen, 1982). 4. Interpolation of temperature data for other sites. Between South Pole and Vostok, a region where the mean annual temperature does not vary greatly, we used the isotherm diagram determined by previous workers (Crary, 1963; Cameron and others, 1968).

The sources are: (1) Jacka and others 1984; (2) Peel and Clausen, 1982; (3) This work; (4) Shimizu, 1964; (5) Lorius and others, 1970; (6) Taylor, 1965; (7) Schwerdtfeger, 1970; (8) Cameron and others, 1968; (9) Crary, 1963; (10) Barkov, 1975. 
Table 2. The results from 104 samples of $1 \mathrm{~m}$ surface snow pits with the geographical position and elevation, measured isotope content for the upper $1 \mathrm{~m}$ snow, estimated mean temperature and accumulation rate. Isotope concentrations are expressed in terms of $\delta^{18} O$, the relative deviations in per mil from the concentration in Standard Mean Ocean Water (Craig, 1961a). SMOW has $\mathrm{D} / \mathrm{H}$ and ${ }^{18} \mathrm{O} /{ }^{16} \mathrm{O}$ ratios respectively equal to 155.76 and $2005.2 \mathrm{ppm}$ (Hagemann and others, 1970; Baerstchi, 1976)

$\begin{array}{cccccccc}\text { Station Position } & \text { Distance } & \begin{array}{c}\text { Eleva- } \\ \text { tion }\end{array} & \delta D & \delta^{18} O & \text { Excess } d \begin{array}{c}\text { Mean } \\ \text { annual Accumul- } \\ \text { ation rate }\end{array} & \text { Location } \\ \text { temper- } \\ \text { ature }\end{array}$

\begin{tabular}{|c|c|c|c|c|c|c|c|c|c|}
\hline 1 & $65^{\circ} 05^{\prime} \mathrm{S}, 59^{\circ} 35^{\prime} \mathrm{W}$ & 0 & 0 & -188.7 & -24.3 & 5.5 & -12.1 & & Seal Nunataks \\
\hline 2 & $65^{\circ} 10^{\prime} \mathrm{S}, 59^{\circ} 59^{\prime} \mathrm{W}$ & 3 & 20 & -154.6 & -19.5 & 1.6 & -12.3 & & \\
\hline 3 & $65^{\circ} 17^{\prime} \mathrm{S}, 60^{\circ} 19^{\prime} \mathrm{W}$ & 11 & 20 & -157.9 & -20.3 & 4.5 & -12.3 & & \\
\hline 4 & $65^{\circ} 27^{\prime} \mathrm{S}, 60^{\circ} 45^{\prime} \mathrm{W}$ & 48 & 20 & -148.8 & -19.0 & 3.4 & -12.4 & & \\
\hline 5 & $65^{\circ} 35^{\prime} \mathrm{S}, 61^{\circ} 10^{\prime} \mathrm{W}$ & 63 & 50 & -156.5 & -19.8 & 2.2 & -12.6 & & \\
\hline 6 & $65^{\circ} 42^{\prime} \mathrm{S}, 61^{\circ} 32^{\prime} \mathrm{W}$ & 76 & 70 & -172.0 & -22.1 & 5.0 & -12.7 & & \\
\hline 7 & $65^{\circ} 50^{\prime} \mathrm{S}, 61^{\circ} 57^{\prime} \mathrm{W}$ & 100 & 90 & -171.5 & -22.1 & 5.5 & -12.9 & & \\
\hline 8 & $66^{\circ} 20^{\prime} \mathrm{S}, 62^{\circ} 36^{\prime} \mathrm{W}$ & 153 & 70 & -177.9 & -22.5 & 2.1 & -12.9 & & \\
\hline 9 & $66^{\circ} 54^{\prime} \mathrm{S}, 63^{\circ} 32^{\prime} \mathrm{W}$ & 249 & 50 & -174.3 & -22.5 & 6.0 & -13.0 & & \\
\hline 10 & $67^{\circ} 20^{\prime} \mathrm{S}, 64^{\circ} 07^{\prime} \mathrm{W}$ & 303 & 50 & -175.2 & -22.8 & 6.9 & -13.1 & & \\
\hline 11 & $67^{\circ} 47^{\prime} \mathrm{S}, 64^{\circ} 42^{\prime} \mathrm{W}$ & 360 & 80 & -174.4 & -22.2 & 3.4 & -13.4 & 60.0 & \\
\hline 12 & $68^{\circ} 25^{\prime} \mathrm{S}, 65^{\circ} 15^{\prime} \mathrm{W}$ & 418 & 200 & -182.7 & -23.7 & 7.1 & -14.3 & & \\
\hline 13 & $68^{\circ} 43^{\prime} \mathrm{S}, 65^{\circ} 26^{\prime} \mathrm{W}$ & 459 & 1200 & -179.9 & -23.3 & 6.9 & -15.8 & & \\
\hline 14 & $68^{\circ} 48^{\prime} \mathrm{S}, 65^{\circ} 22^{\prime} \mathrm{W}$ & 465 & 1250 & -183.0 & -23.6 & 5.7 & -16.0 & & \\
\hline 15 & $68^{\circ} 57^{\prime} \mathrm{S}, 65^{\circ} 26^{\prime} \mathrm{W}$ & 473 & 1350 & -189.7 & -24.5 & 7.8 & -16.5 & 50.0 & \\
\hline 16 & $69^{\circ} 04^{\prime} \mathrm{S}, 65^{\circ} 20^{\prime} \mathrm{W}$ & 488 & 1400 & -180.4 & -23.5 & 7.3 & -17.0 & & \\
\hline 17 & $69^{\circ} 10^{\prime} \mathrm{S}, 65^{\circ} 18^{\prime} \mathrm{W}$ & 497 & 1700 & -187.3 & -24.2 & 6.4 & -17.3 & & Weyerhaeuser Glacier \\
\hline 18 & $69^{\circ} 41^{\prime} \mathrm{S}, 65^{\circ} 13^{\prime} \mathrm{W}$ & 570 & 1600 & -188.3 & -24.1 & 4.2 & -19.6 & 16.4 & \\
\hline 19 & $70^{\circ} 25^{\prime} \mathrm{S}, 64^{\circ} 44^{\prime} \mathrm{W}$ & 607 & 1950 & -211.8 & -27.3 & 7.0 & -19.8 & 16.4 & \\
\hline 20 & $70^{\circ} 58^{\prime} \mathrm{S}, 64^{\circ} 41^{\prime} \mathrm{W}$ & 676 & 2000 & -220.6 & -28.3 & 5.5 & -21.3 & & \\
\hline 21 & $71^{\circ} 17^{\prime} \mathrm{S}, 65^{\circ} 43^{\prime} \mathrm{W}$ & 708 & 1650 & -195.2 & -25.0 & 4.3 & -20.7 & & \\
\hline 22 & $71^{\circ} 56^{\prime} \mathrm{S}, 65^{\circ} 18^{\prime} \mathrm{W}$ & 782 & 1250 & -185.1 & -23.3 & 1.5 & -18.1 & & \\
\hline 23 & $72^{\circ} 14^{\prime} \mathrm{S}, 65^{\circ} 29^{\prime} \mathrm{W}$ & 814 & 1250 & -199.7 & -25.3 & 2.4 & -18.1 & & \\
\hline 24 & $72^{\circ} 33^{\prime} \mathrm{S}, 65^{\circ} 55^{\prime} \mathrm{W}$ & 851 & 1000 & -203.8 & -26.6 & 8.9 & -16.4 & & \\
\hline 25 & $73^{\circ} 14^{\prime} \mathrm{S}, 66^{\circ} 48^{\prime} \mathrm{W}$ & 929 & 1200 & -188.6 & -24.3 & 5.9 & -18.3 & & \\
\hline 26 & $73^{\circ} 56^{\prime} \mathrm{S}, 67^{\circ} 30^{\prime} \mathrm{W}$ & 1014 & 1300 & -140.1 & -18.2 & 5.3 & -20.0 & 50.0 & \\
\hline 27 & $74^{\circ} 05^{\prime} \mathrm{S}, 69^{\circ} 57^{\prime} \mathrm{W}$ & 1101 & 1450 & -193.8 & -25.0 & 6.2 & -20.0 & 33.8 & \\
\hline 28 & $74^{\circ} 46^{\prime} \mathrm{S}, 72^{\circ} 46^{\prime} \mathrm{W}$ & 1217 & 1520 & -210.0 & -27.0 & 6.3 & -22.1 & 25.1 & \\
\hline 29 & $74^{\circ} 51^{\prime} \mathrm{S}, 75^{\circ} 45^{\prime} \mathrm{W}$ & 1302 & 700 & -213.9 & -27.7 & 8.1 & -23.0 & 26.5 & \\
\hline 30 & $75^{\circ} 26^{\prime} \mathrm{S}, 78^{\circ} 29^{\prime} \mathrm{W}$ & 1400 & 450 & -239.6 & -30.7 & 5.6 & -24.8 & 22.8 & Eights \\
\hline 31 & $75^{\circ} 47^{\prime} \mathrm{S}, 81^{\circ} 40^{\prime} \mathrm{W}$ & 1503 & 750 & -246.4 & -31.7 & 7.4 & -25.8 & & \\
\hline 32 & $76^{\circ} 25^{\prime} \mathrm{S}, 85^{\circ} 10^{\prime} \mathrm{W}$ & 1569 & 1050 & -258.2 & -32.9 & 5.3 & -27.7 & 34.4 & \\
\hline 33 & $76^{\circ} 56^{\prime} \mathrm{S}, 86^{\circ} 15^{\prime} \mathrm{W}$ & 1633 & 1100 & -255.8 & -32.6 & 5.2 & -27.9 & & \\
\hline 34 & $77^{\circ} 39^{\prime} \mathrm{S}, 87^{\circ} 07^{\prime} \mathrm{W}$ & 1703 & 1500 & -248.4 & -31.8 & 6.3 & -29.9 & & \\
\hline 35 & $78^{\circ} 12^{\prime} \mathrm{S}, 87^{\circ} 39^{\prime} \mathrm{W}$ & 1761 & 1650 & -251.9 & -32.0 & 3.8 & -30.6 & 40.0 & \\
\hline 36 & $78^{\circ} 49^{\prime} \mathrm{S}, 87^{\circ} 14^{\prime} \mathrm{W}$ & 1838 & 2050 & -295.4 & -37.5 & 4.2 & -32.1 & 30.0 & \\
\hline 37 & $79^{\circ} 10^{\prime} \mathrm{S}, 86^{\circ} 51^{\prime} \mathrm{W}$ & 1872 & 1800 & -363.3 & -33.2 & 2.6 & -31.2 & & \\
\hline 38 & $79^{\circ} 45^{\prime} \mathrm{S}, 85^{\circ} 18^{\prime} \mathrm{W}$ & 1946 & 1680 & -296.2 & -37.5 & 3.6 & -30.7 & 20.0 & \\
\hline 39 & $80^{\circ} 18^{\prime} \mathrm{S}, 81^{\circ} 21^{\prime} \mathrm{W}$ & 2092 & 700 & -263.6 & -33.4 & 3.7 & -27.3 & & Patriot Hills \\
\hline 40 & $80^{\circ} 45^{\prime} \mathrm{S}, 81^{\circ} 15^{\prime} \mathrm{W}$ & 2116 & 900 & -271.0 & -34.9 & 8.3 & -27.3 & & \\
\hline 41 & $81^{\circ} 12^{\prime} \mathrm{S}, 82^{\circ} 00^{\prime} \mathrm{W}$ & 2148 & 900 & -289.3 & -36.9 & 6.2 & -28.2 & & \\
\hline 42 & $81^{\circ} 48^{\prime} \mathrm{S}, 82^{\circ} 50^{\prime} \mathrm{W}$ & 2224 & 1050 & -280.1 & -35.7 & 5.6 & -29.1 & & \\
\hline 43 & $81^{\circ} 55^{\prime} \mathrm{S}, 83^{\circ} 20^{\prime} \mathrm{W}$ & 2263 & 1150 & -303.9 & -37.8 & -1.2 & -29.7 & & \\
\hline 44 & $82^{\circ} 41^{\prime} \mathrm{S}, 84^{\circ} 00^{\prime} \mathrm{W}$ & 2329 & 1250 & -300.0 & -38.1 & 4.7 & -30.9 & & \\
\hline 45 & $83^{\circ} 05^{\prime} \mathrm{S}, 84^{\circ} 45^{\prime} \mathrm{W}$ & 2369 & 1320 & -300.6 & -38.4 & 6.9 & -31.5 & & \\
\hline 46 & $83^{\circ} 47^{\prime} \mathrm{S}, 87^{\circ} 25^{\prime} \mathrm{W}$ & 2446 & 1480 & -317.7 & -40.0 & 2.1 & -33.1 & 15.0 & \\
\hline 47 & $84^{\circ} 12^{\prime} \mathrm{S}, 88^{\circ} 05^{\prime} \mathrm{W}$ & 2490 & 1550 & -311.3 & -39.2 & 2.6 & -3.9 & & \\
\hline 48 & $84^{\circ} 35^{\prime} \mathrm{S}, 88^{\circ} 55^{\prime} \mathrm{W}$ & 2534 & 1650 & -321.3 & -40.8 & 5.4 & -34.8 & & \\
\hline 49 & $85^{\circ} 11^{\prime} \mathrm{S}, 88^{\circ} 58^{\prime} \mathrm{W}$ & 2622 & 1730 & -339.1 & -42.8 & 3.4 & -36.8 & & \\
\hline 50 & $85^{\circ} 53^{\prime} \mathrm{S}, 88^{\circ} 10^{\prime} \mathrm{W}$ & 2709 & 1850 & -314.8 & -40.6 & 10.2 & -39.2 & & Thiel Mountains \\
\hline 51 & $86^{\circ} 12^{\prime} \mathrm{S}, 88^{\circ} 25^{\prime} \mathrm{W}$ & 2746 & 2000 & -344.2 & -43.6 & 4.8 & -40.3 & 10.0 & \\
\hline 52 & $86^{\circ} 34^{\prime} \mathrm{S}, 88^{\circ} 57^{\prime} \mathrm{W}$ & 2828 & 2050 & -353.5 & -45.0 & 6.3 & -41.6 & & \\
\hline 53 & $86^{\circ} 54^{\prime} \mathrm{S}, 90^{\circ} 19^{\prime} \mathrm{W}$ & 2875 & 2200 & -335.7 & -42.3 & 2.9 & -42.7 & & \\
\hline 54 & $87^{\circ} 36^{\prime} \mathrm{S}, 91^{\circ} 06^{\prime} \mathrm{W}$ & 2946 & 2380 & -371.3 & -47.6 & 9.1 & -45.1 & & \\
\hline
\end{tabular}


$87^{\circ} 57^{\prime} \mathrm{S}, 91^{\circ} 55^{\prime} \mathrm{W}$ $88^{\circ} 38^{\prime} \mathrm{S}, 92^{\circ} 26^{\prime} \mathrm{W}$ $89^{\circ} 00^{\prime} \mathrm{S}, 92^{\circ} 58^{\prime} \mathrm{W}$ $89^{\circ} 22^{\prime} \mathrm{S}, 91^{\circ} 39^{\prime} \mathrm{W}$ $90^{\circ} 00^{\prime} \mathrm{S}$

$89^{\circ} 53^{\prime} \mathrm{S}, 114^{\circ} 22^{\prime} \mathrm{E}$ $89^{\circ} 32^{\prime} \mathrm{S}, 108^{\circ} 18^{\prime} \mathrm{E}$ $89^{\circ} 11^{\prime} \mathrm{S}, 105^{\circ} 35^{\prime} \mathrm{E}$ $88^{\circ} 26^{\prime} \mathrm{S}, 104^{\circ} 27^{\prime} \mathrm{E}$ $88^{\circ} 03^{\prime} \mathrm{S}, 104^{\circ} 35^{\prime} \mathrm{E}$ $87^{\circ} 42^{\prime} \mathrm{S}, 104^{\circ} 39^{\prime} \mathrm{E}$ $87^{\circ} 20^{\prime} \mathrm{S}, 104^{\circ} 25^{\prime} \mathrm{E}$ $86^{\circ} 36^{\prime} \mathrm{S}, 104^{\circ} 57^{\prime} \mathrm{E}$ $85^{\circ} 33^{\prime} \mathrm{S}, 105^{\circ} 40^{\prime} \mathrm{E}$ $85^{\circ} 13^{\prime} \mathrm{S}, 105^{\circ} 49^{\prime} \mathrm{E}$ $84^{\circ} 28^{\prime} \mathrm{S}, 106^{\circ} 17^{\prime} \mathrm{E}$ $84^{\circ} 07^{\prime} \mathrm{S}, 106^{\circ} 17^{\prime} \mathrm{E}$ $83^{\circ} 44^{\prime} \mathrm{S}, 106^{\circ} 24^{\prime} \mathrm{E}$ $83^{\circ} 00^{\prime} \mathrm{S}, 106^{\circ} 12^{\prime} \mathrm{E}$ $82^{\circ} 40^{\prime} \mathrm{S}, 106^{\circ} 19^{\prime} \mathrm{E}$ $81^{\circ} 50^{\prime} \mathrm{S}, 106^{\circ} 28^{\prime} \mathrm{E}$ $81^{\circ} 05^{\prime} \mathrm{S}, 106^{\circ} 26^{\prime} \mathrm{E}$ $80^{\circ} 42^{\prime} \mathrm{S}, 106^{\circ} 12^{\prime} \mathrm{E}$ $80^{\circ} 17^{\prime} \mathrm{S}, 106^{\circ} 14^{\prime} \mathrm{E}$ $79^{\circ} 42^{\prime} \mathrm{S}, 106^{\circ} 04^{\prime} \mathrm{E}$ $79^{\circ} 08^{\prime} \mathrm{S}, 106^{\circ} 08^{\prime} \mathrm{E}$ $78^{\circ} 46^{\prime} \mathrm{S}, 106^{\circ} 41^{\prime} \mathrm{E}$ $78^{\circ} 07^{\prime} \mathrm{S}, 105^{\circ} 47^{\prime} \mathrm{E}$ $77^{\circ} 43^{\prime} \mathrm{S}, 104^{\circ} 47^{\prime} \mathrm{E}$ $77^{\circ} 00^{\prime} \mathrm{S}, 102^{\circ} 55^{\prime} \mathrm{E}$ $76^{\circ} 36^{\prime} \mathrm{S}, 102^{\circ} 00^{\prime} \mathrm{E}$ $75^{\circ} 54^{\prime} \mathrm{S}, 100^{\circ} 31^{\prime} \mathrm{E}$ $75^{\circ} 33^{\prime} \mathrm{S}, 100^{\circ} 31^{\prime} \mathrm{E}$ $74^{\circ} 44^{\prime} \mathrm{S}, \quad 98^{\circ} 41^{\prime} \mathrm{E}$ $74^{\circ} 21^{\prime} \mathrm{S}, \quad 98^{\circ} 00^{\prime} \mathrm{E}$ $73^{\circ} 41^{\prime} \mathrm{S}, \quad 97^{\circ} 26^{\prime} \mathrm{E}$ $73^{\circ} 18^{\prime} \mathrm{S}, \quad 97^{\circ} 09^{\prime} \mathrm{E}$ $72^{\circ} 51^{\prime} \mathrm{S}, \quad 96^{\circ} 59^{\prime} \mathrm{E}$ $72^{\circ} 28^{\prime} \mathrm{S}, \quad 96^{\circ} 45^{\prime} \mathrm{E}$ $71^{\circ} 42^{\prime} \mathrm{S}, \quad 96^{\circ} 17^{\prime} \mathrm{E}$ $71^{\circ} 20^{\prime} \mathrm{S}, \quad 96^{\circ} 01^{\prime} \mathrm{E}$ $70^{\circ} 57^{\prime} \mathrm{S}, \quad 95^{\circ} 54^{\prime} \mathrm{E}$ $70^{\circ} 33^{\prime} \mathrm{S}, \quad 95^{\circ} 43^{\prime} \mathrm{E}$ $70^{\circ} 11^{\prime} \mathrm{S}, \quad 95^{\circ} 35^{\prime} \mathrm{E}$ $69^{\circ} 46^{\prime} \mathrm{S}, \quad 95^{\circ} 22^{\prime} \mathrm{E}$ $69^{\circ} 26^{\prime} \mathrm{S}, \quad 95^{\circ} 07^{\prime} \mathrm{E}$ $68^{\circ} 51^{\prime} \mathrm{S}, 94^{\circ} 37^{\prime} \mathrm{E}$ $68^{\circ} 05^{\prime} \mathrm{S}, \quad 93^{\circ} 50^{\prime} \mathrm{E}$ $67^{\circ} 42^{\prime} \mathrm{S}, \quad 93^{\circ} 39^{\prime} \mathrm{E}$ $67^{\circ} 21^{\prime} \mathrm{S}, \quad 93^{\circ} 26^{\prime} \mathrm{E}$ $66^{\circ} 33^{\prime} \mathrm{S}, \quad 93^{\circ} 00^{\prime} \mathrm{E}$

$\begin{array}{ll}2984 & 2550 \\ 3062 & 2650 \\ 3100 & 2750 \\ 3141 & 2850 \\ 3207 & 2880 \\ 3220 & 2880 \\ 3259 & 2900 \\ 3297 & 2950 \\ 3382 & 3050 \\ 3424 & 3070 \\ 3463 & 3130 \\ 3504 & 3150 \\ 3585 & 3150 \\ 3703 & 3160 \\ 3740 & 3180 \\ 3824 & 3210 \\ 3863 & 3230 \\ 3905 & 3230 \\ 3986 & 3260 \\ 4024 & 3280 \\ 4117 & 3310 \\ 4200 & 3410 \\ 4243 & 3400 \\ 4289 & 3420 \\ 4354 & 3430 \\ 4418 & 3430 \\ 4460 & 3480 \\ 4535 & 3500 \\ 4585 & 3510 \\ 4677 & 3550 \\ 4727 & 3550 \\ 4814 & 3560 \\ 4854 & 3550 \\ 4959 & 3550 \\ 5006 & 3500 \\ 5082 & 3490 \\ 5126 & 3430 \\ 5176 & 3380 \\ 5220 & 3320 \\ 5306 & 3180 \\ 5348 & 3090 \\ 5391 & 2980 \\ 5436 & 2870 \\ 5477 & 2820 \\ 5524 & 2720 \\ 5562 & 2650 \\ 5630 & 2400 \\ 5721 & 2080 \\ 5765 & 1850 \\ 5805 & 1480 \\ 5896 & 41 \\ & \end{array}$

$-378.5$

$-386.7$

$-386.7$

$-394.5$

$-395.4$

$-398.3$

$-404.7$

$-403.2$

$-398.7$

$-413.8$

$-415.0$

$-416.6$

$-415.2$

$-418.7$

$-422.5$

$-427.8$

$-432.2$

$-426.1$

$-430.0$

$-436.5$

$-422.5$

$-436.6$

$-435.1$

$-446.9$

$-440.7$

$-414.5$

$-453.7$

$-441.1$

$-425.0$

$-414.7$

$-427.9$

$-417.7$

$-423.9$

$-416.4$

$-407.0$

$-399.2$

$-387.6$

$-375.3$

$-364.9$

$-344.2$

$-353.4$

$-351.0$

$-335.1$

$-322.6$

$-290.8$

$-283.4$

$-298.7$

$-248.6$

$-229.6$

$-202.9$

$-164.6$
8.2

8.0

7.6

8.1

8.5 South Pole

2.3

Vostok Station

$-55.5$

$-5.4$

$-55.2$

$-54.6$

$-54.3$

$-53.7$

$-53.4$

$-52.9$

$-52.6$

$-50.7$

$-49.6$

$-48.3$

$-47.1$

$-45.3$

$-43.9$

$-42.5$

$-41.1$

$-39.7$

$-38.0$

$-35.5$

$-31.0$

$-27.7$

$-24.1$

$-20.9$
2.3

3.0

3.3

3.6

3.7

3.7

3.7

6.6

6.1

7.1

7.8

9.1

12.3

12.3

12.9

12.6

16.0

12.6

11.2

10.8

18.9

40.3

49.0
Komsomolskaya

Vostok-1

Pionerskaya

Mirny latitude effect. They are distributed mainly throughout regions of West Antarctica, particularly on the Larsen Ice Shelf, the Antarctic Peninsula and the mountain regions. In order to estimate these temperatures, altitude and latitude effects must be known and account must be taken of peculiarities, such as the fact that the Antarctic Peninsula is a natural barrier which demarcates a distinct climatic division between a maritime climate in the west and a continental climate in the east (Schwerdtfeger, 1970; Aristarain and others, 1986).

For example, we estimated the temperatures on the Larsen Ice Shelf, (from station 1 to 12) using data from Esperanza Station $\left(63^{\circ} 24^{\prime} \mathrm{S}, 57^{\circ} 00^{\prime} \mathrm{W}\right.$; mean annual temperature of $-5.3^{\circ} \mathrm{C}$ at $7 \mathrm{~m}$ a.s.1.; Schwerdtfeger,
1975 ) and James Ross Island $\left(64^{\circ} 13^{\prime} \mathrm{S}, 57^{\circ} 54^{\prime} \mathrm{W}\right.$, $-14.3^{\circ} \mathrm{C}$ at $1640 \mathrm{~m}$ a.s.l.; Aristarain and others, 1986), two sites with very close geographic positions and different altitudes. For this area, the estimated lapse rate is about $0.56^{\circ} \mathrm{C} / 100 \mathrm{~m}$. As the next step, we chose Matienzo Station $\left(-12.1^{\circ} \mathrm{C}\right.$ as the temperature at sea level; Jacka and others, 1984) and Gipps Ice Rise $\left(68^{\circ} 46^{\prime} \mathrm{S}, 60^{\circ} 56^{\prime} \mathrm{W} ;-14.9^{\circ} \mathrm{C}\right.$ as the $10 \mathrm{~m}$ snow temperature and $290 \mathrm{~m}$ a.s.l.; Peel and Clausen, 1982) to calculate the latitudinal effect which is equal to $0.316^{\circ} \mathrm{C}$ per degree of latitude in this region.

We have to estimate the lapse rate and the latitudinal effect separately for each region because of the different geographic conditions. From station 13 to 18 in Palmer 
Land, part of the Antarctic Peninsula, the elevation increases and the temperature decreases. The two stations that are considered as the reference stations in this region are station 12 and Peninsula Plateau Crest $\left(70^{\circ} 01^{\prime} \mathrm{S}\right.$, $64^{\circ} 29^{\prime} \mathrm{W}$ ) with a $10 \mathrm{~m}$ snow temperature of $-21^{\circ} \mathrm{C}$ at $2131 \mathrm{~m}$ a.s.l. (Peel and Clausen, 1982). We then obtained the temperature of each of the sampling stations by latitudinal effect only (Table 2). The temperature measured at station $17\left(-17.3^{\circ} \mathrm{C}\right)$ is remarkably similar to the estimated value of $-17.4^{\circ} \mathrm{C}$ which gives confidence in the extrapolation method.

From station 19 to 36 , the sampling sites are all in a mountainous area which makes it difficult to estimate the temperature with the method that we used for the Larsen Ice Shelf. However, the mean annual temperature was already known for nine sites on or very near the route (Schwerdtfeger, 1970; Peel and Clausen, 1982; Peel and others, 1988). This makes it possible to calculate the lapse rate and latitudinal effect and to estimate the temperature. From station 37 to the South Pole, we derived the mean annual temperature from three sites close to the route (Lorius and others, 1970; Jacka and others, 1984). From Vostok to Mirny, the temperature was simply calculated for each site assuming a linear interpolation between known sites (i.e. meteorological data or $10 \mathrm{~m}$ pit temperatures).

The temperature along the route is shown on Figure 2b. As various approaches were used, it is difficult to quantify the errors associated with each of these figures but the overall accuracy is probably no better than $1^{\circ} \mathrm{C}$. Although relatively high, it does not in general limit the climatic interpretation of this new set of isotopic data (see section 4).

\subsection{Representativeness of the samples}

The time period covered by the samples from each site depends on the accumulation rate that we derived largely from the compilation of Giovinetto and Bull (1987). We used additional data from shallow ice cores and shallow snow pits which covered several tens of years and several years of snow accumulation, respectively (Shimizu, 1964; Taylor, 1965; Hamilton and O'Kelley, 1971; Kotlyakov and others, 1977; Lipenkov, 1980; Peel and Clausen, 1982; Jouzel and others, 1983).

There are 63 stations from which we have not yet been able to obtain good accumulation data, because they are mainly in regions not far from the coast, and their altitudes vary significantly. Our evidence suggests that the accumulation at these stations should vary rapidly with distance, as is the case, for example, in the Larsen Ice Shelf, Antarctic Peninsula and Ellsworth Mountains areas. Figure 3 shows the general distribution of the snow-accumulation rate along the route. The measured snow density in several snow pits indicates that the mean snow density in a $1 \mathrm{~m}$ snow pit is usually from 0.3 to $0.4 \mathrm{Mg} \mathrm{m}^{-3}$ (Qin Dahe and Ren Jiawen, 1991).

The period covered at each site therefore varies from $\sim 1$ to 15 years as shown in Figure 3 (assuming a mean density of $\sim 0.35 \mathrm{Mg} \mathrm{m}^{-3}$ ). However, the coverage may be less than 1 year as at station $26\left(73^{\circ} 56^{\prime} \mathrm{S}, 67^{\circ} 30^{\prime} \mathrm{W}\right)$, located in an area of the English Coast, where the accumulation is much higher than that of the adjacent

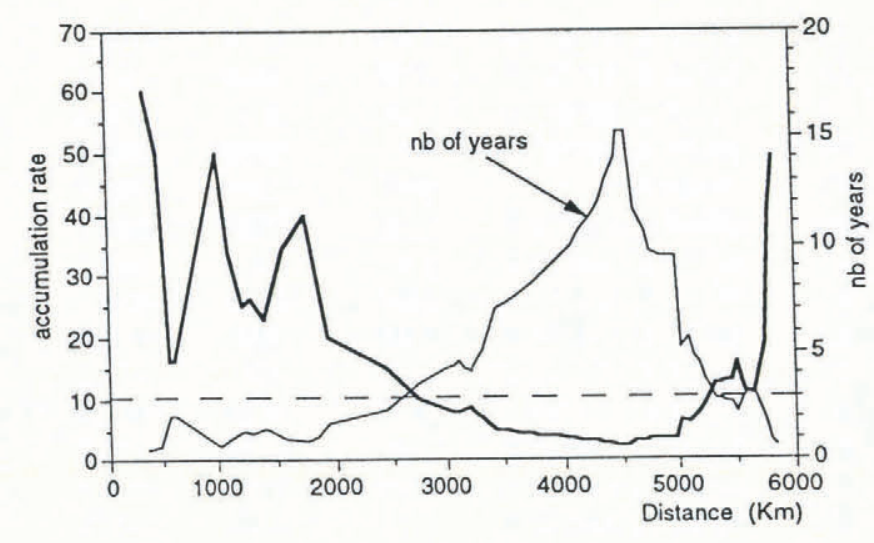

Fig. 3. Estimated accumulation rate $\left(\mathrm{g} \mathrm{cm}^{-2} \mathrm{a}^{-1}\right)$ and number of years represented by the $1 \mathrm{~m}$ of snow sampled along the traverse route. The horizontal line corresponds to a 3 year snow sequence.

stations. The stratigraphy there shows that the thickness of new snow is $48 \mathrm{~cm}$, with a very low density, $0.09 \mathrm{Mg} \mathrm{m}^{3}$ (Qin Dahe and Ren Jiawen, 1991). This snow fell in a 1 day snowfall on 29 September 1989, and the stratigraphy observation was made on the following morning. Below $48 \mathrm{~cm}$, there is an "old" soft snow layer of $69 \mathrm{~cm}$ thickness, with a density of $0.12 \mathrm{Mg} \mathrm{m}^{-3}$. The density at $1.17-1.20 \mathrm{~m}$ depth is $0.27 \mathrm{Mg} \mathrm{m}^{-3}$. These facts show that the $1 \mathrm{~m}$ surface snow of station 26 only includes a few snowfalls that occurred during a short period and the results obtained from such a snow pit cannot be considered representative for determining the average
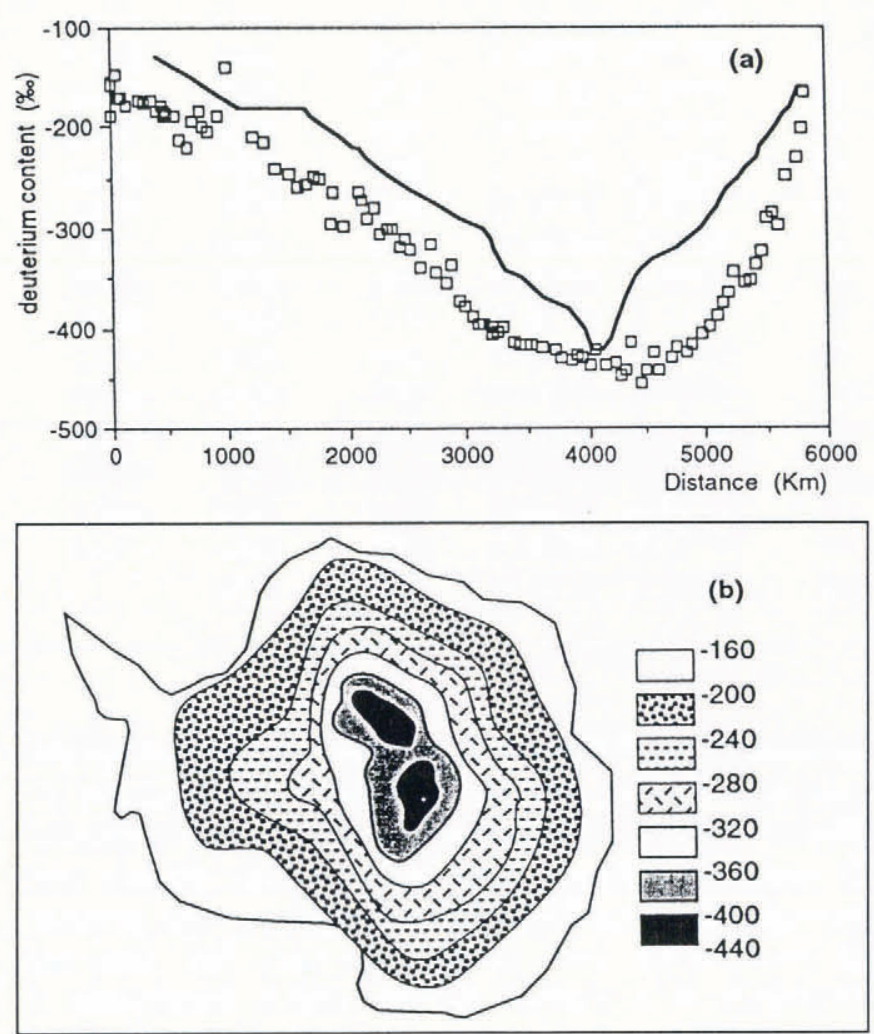

Fig. 4. a. Measured deuterium content (open square) versus distance along the traverse route and deuterium content (continuous line) as predicted by the NASA/GISS model (Jouzel and others, 1987a) along the same route. $b$. Isopleth of deuterium content as predicted by the NASA/ GISS model for Antarctica. 
isotopic composition. More generally, data lying below the stippled line in Figure 3 are based on less than 3 years' accumulation and must be interpreted cautiously.

Ideally, multiple sampling should have been done at some selected sites to assess the errors caused by drift noise and wind erosion or scouring, but this was not possible. Earlier studies such as those by Petit and others (1982) show that such local variability is well below $10 \%$ for $\delta \mathrm{D}$. Figure $4 \mathrm{a}$ shows well that, although very useful, such multiple sampling is not essential for the climatic interpretation we develop in this article.

\subsection{Isotopic measurements}

All of the samples were kept frozen and transported from Antarctica to the low-temperature storage facility $\left(\sim-25^{\circ} \mathrm{C}\right)$ in France. The samples were melted just before determination of the isotopes. Average samples were prepared for each snow pit by combining $3 \mathrm{ml}$ of water from each melted sample from one snow pit (usually four samples for each $1 \mathrm{~m}$ snow pit, except for stations 1 to 6 ).

The deuterium and oxygen- 18 contents of the average samples were measured by mass spectrometry at the Laboratoire de Modélisation du Climat et de l'Environnement, Saclay, France. The analytical results are given for both $\delta \mathrm{D}$ and $\delta^{18} \mathrm{O}$ as follows:

$$
\delta(\%)=\left[\left(\mathbf{R}_{\text {sample }}-\mathbf{R}_{\text {standard }}\right) / \mathbf{R}_{\text {standard }}\right] \times 1000 .
$$

The accuracies of the measurements are $\pm 0.5 \%$ and $\pm 0.15 \%$ for individual $\delta \mathrm{D}$ and $\delta^{18} \mathrm{O}$, respectively. The results are listed in Table 2.

\section{GEOGRAPHICAL DISTRIBUTION}

We will present the characteristics of the water isotope distribution, focusing on two parameters: the route distance and the elevation of the site. Since the deuterium and oxygen-18 geographical distributions are quite similar, the discussion can be limited to one of the isotopic species and it will be given here with respect to the deuterium results. Given the large geographical coverage of the Trans-Antarctica Expedition, it is interesting to compare the results with those obtained from the general circulation models mentioned in the Introduction.

Figure $5 \mathrm{a}$ gives a distribution of $\delta \mathrm{D}$ in the $1 \mathrm{~m}$ surface snow with respect to the distance to the Seal Nunataks as well as the distribution predicted by the NASA/GISS model. Most of the variation between successive values is smooth, particularly after Patriot Hills, $2000 \mathrm{~km}$ from the start. There are, nevertheless, several values that stand out from the main trend of the curve, such as the high value of $\delta \mathrm{D}$ at station 26 . This is attributed to the fact that it represents several large snowfalls that occurred only a short time before collection (see above discussion). The $\delta \mathrm{D}$ value at this station is $-140.1 \%$, which is $50 \%$ higher than the adjacent values. More generally, in the Antarctic Peninsula region, several values of $\delta \mathrm{D}$ deviate from the main trend. Most probably, this is due to parameters such as the elevation and the distance from the coast or openwater line. Other, but less striking, examples concern

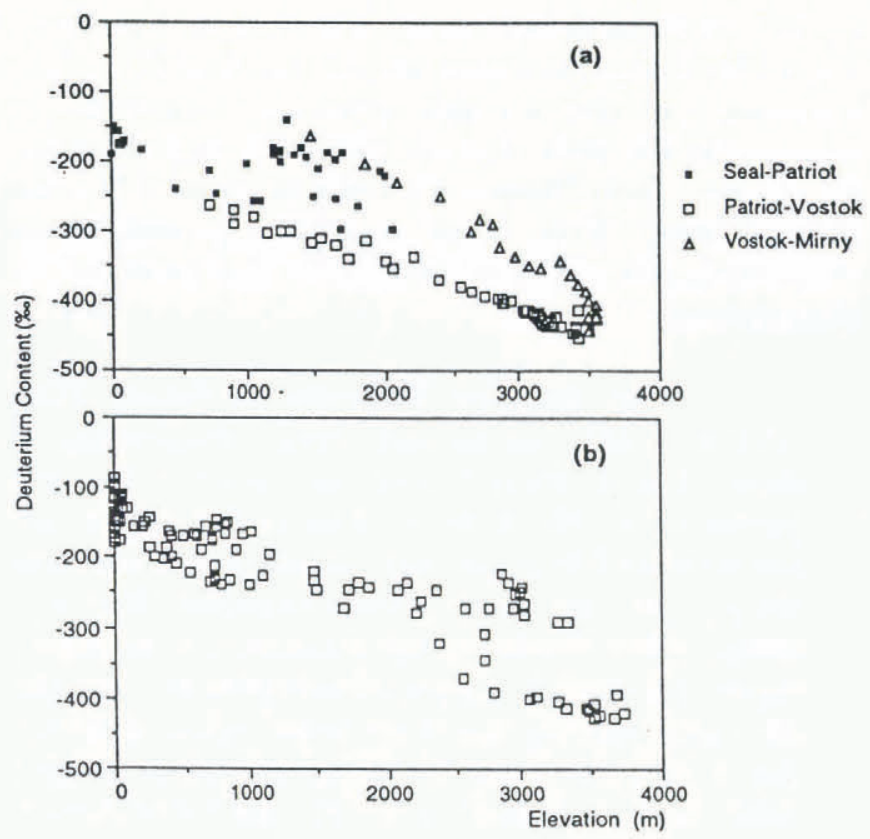

Fig. 5. a. Relationship between $\delta D$ and elevation along the traverse route for the different parts of Antarctica. Solid squares: from Seal Nunataks to Patriot Hills; open squares: from Patriot Hills to Vostok; open triangles: from Vostok to Mirny. b. Relationship between $\delta D$ and elevation over Antarctica as predicted by the NASA/GISS model (Jouzel and others, 1987a).

stations 79 and 82 , although they are located in a region of very low accumulation near Vostok Station and the sampling represents more than 10 years of accumulation. The isotope content seems to differ by $20-30 \%$ from the general trend. We have noted that the snow stratigraphy at the two stations is different from that at the adjacent stations owing to the presence of thick depth hoar which may affect the snow isotopic content (because the depth hoar is formed by sublimation and condensation processes).

Figure $4 \mathrm{~b}$ shows the annual average of the deuterium content of precipitation over Antarctica as predicted by the NASA/GISS general circulation model (Jouzel and others, 1987a). The general pattern is correctly simulated, however, the predicted values are systematically higher than those observed as illustrated in Figure 4a. For example, the region with a deuterium content below $-400 \%$ is underestimated by the model and the lowest predicted value in Antarctica (i.e. $-430 \%$ ) is $25 \%$ above the lowest observed one $(-454 \%)$. As noted by Jouzel and others (1987a), the difference may be partly explained by the slight overestimation of the predicted temperature on the Antarctic Plateau, with a predicted minimum of $-55^{\circ} \mathrm{C}$ compared to $-58^{\circ} \mathrm{C}$. This defect, resulting in too high predicted temperatures over Antarctica, is much more accentuated and prevents a useful comparison of predicted and observed isotopic distributions for the LMD (Laboratoire de Météorologie Dynamique, Paris) model (Joussaume and Jouzel, 1993). The comparison in Figure 4 also suffers from the coarse grid size of the GISS model $\left(8^{\circ} \times 10^{\circ}\right)$; nevertheless it illustrates well the usefulness of having a large spatial data coverage for such an approach. 
The relationship between $\delta \mathrm{D}$ and elevation is given in Figure 5a. Except at station 26, the high/low $\delta D$ values correspond to the low/high elevation. This type of relationship has been observed previously in Antarctica, for example, from Dumont d'Urville to Dome C (Lorius and Merlivat, 1977), where there is a general linear relationship between elevation and $\delta \mathrm{D}$. Four parts can be distinguished:

(1) From the Seal Nunataks to Patriot Hills (station 1-39), no obvious linear relationship is observed and many factors can account for this phenomenon. All of the stations in this region are not far inland from the coast or the open water and the precipitation has a cyclonic character (Peel and others, 1988). Similar to the situation in a mountain region, the isotopic content of precipitation from the air masses moving near the coastal regions does not change very much with the surface elevations (Robin, 1983). Lorius and Merlivat (1977) found that there is almost no change of $\delta \mathrm{D}$ when the elevation is less than $1000 \mathrm{~m}$ in the coastal area near Dumont d'Urville Station. Kato (1977) reached a similar conclusion in the Syowa Station area. The same was observed by Koerner (1979) in the Arctic.

(2) A rather good monotonic relationship between $\delta \mathrm{D}$ and the elevation can be seen from Patriot Hills in West Antarctica to the east of Vostok Station (station 81 ) and represented by the lower values in Figure 5a.

(3) From Vostok to Komsomolskaya (station 89), at the top of the Antarctic Plateau, the $\delta \mathrm{D}$ values increase steeply by about $40 \%$ continuously, despite an almost constant elevation (3500-3560 m).

(4) A monotonic decreasing trend is observed from Komsomolskaya to Mirny.

Our results confirm that the $\delta \mathrm{D}$ content in the surface of the Antarctic ice sheet tends to decrease generally with increasing elevation, although the gradient differs for the various geographic zones. The previous studies have already taken note of this situation qualitatively (Gonfiantini and others, 1963; Picciotto, 1967; Lorius and others, 1970; Dansgaard and others, 1973; Lorius and Merlivat, 1977). At the same time, we observed that on top of the Plateau, around $3500 \mathrm{~m}$ a.s.l., the value of $\delta \mathrm{D}$ changes continuously, even though the elevation does not change very much.

Note that, from the viewpoint of a Rayleigh model, neither the altitude nor the distance to the coast are driving parameters for determining the isotopic content of precipitation; the pressure change directly linked with altitude has only a marginal influence. In such a model, the two key parameters are the temperature at the site and, to a lesser degree, the temperature of evaporation. The observed relationship between the altitude and the isotopic content of snow is mainly a result of the general temperature decrease with increasing altitude. This relationship is relatively well captured by GCM's isotopic models as shown in Figure 5b, on which we have reported the predicted $\delta \mathrm{D}$ for precipitation with respect to the grid-size elevation for all Antarctic grid boxes.

\section{ISOTOPES AND MEAN ANNUAL TEMPERATURE}

In Figure $6 \mathrm{a}$, the $\delta \mathrm{D}$ values are plotted with respect to the mean annual surface temperature, $T_{\mathrm{s}}$. The results from west of Vostok are systematically lower than results east of Vostok, suggesting that two regression lines should be calculated. For the western part, we further think it is preferable to use only the results from Patriot Hills to Vostok (Fig. 6b), because from the Seal Nunataks to Patriot Hills the $1 \mathrm{~m}$ samples represent only a short time period and possibly, in some cases, only one season, which makes the result sensitive to the date of sample collection (which has only a marginal influence for low-accumulation sites). Indeed, for this segment, there is no very clear linear relationship and we will limit ourselves to a comparison with oxygen-18 of previous work for this area (see below). In the eastern part, we calculated the regression line between Komsomolskaya and Mirny (Fig. $6 c)$. The two regression lines are:

$$
\begin{aligned}
\delta \mathrm{D}\left(\%_{0}\right) & =5.84 T_{\mathrm{s}}-113.6 \text { (Patriot Hills to Vostok) } \\
r^{2} & =0.96 \\
\delta \mathrm{D}\left(\%_{0}\right) & =7.00 T_{\mathrm{B}}-30.2 \text { (Komsomolskaya to Mirny) } \\
r^{2} & =0.98
\end{aligned}
$$
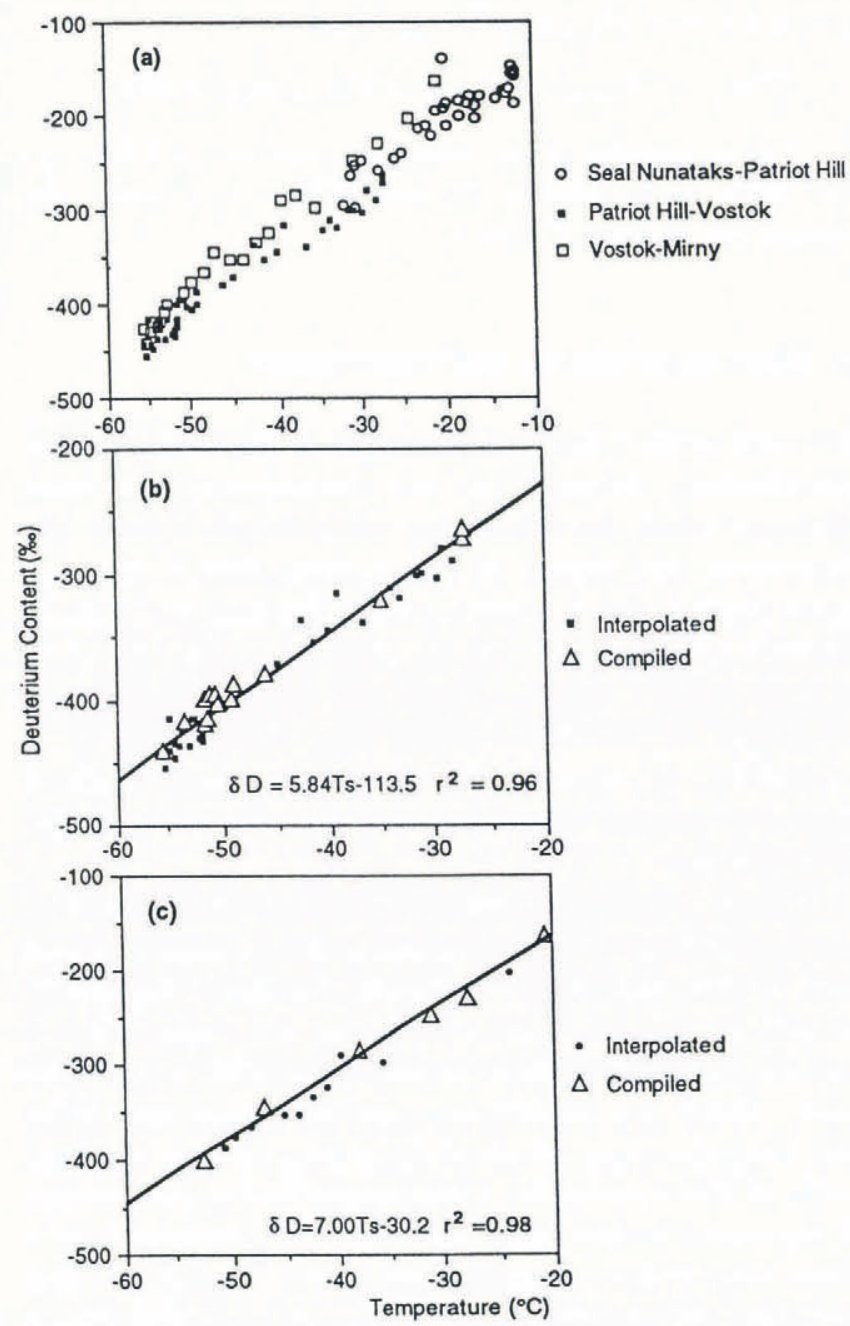

Fig. 6. Relationship between $\delta D$ and temperature. a. All data along the traverse route. $b$. From Patriot Hills to Vostok. c. From Komsomolskaya to Mirny. The open triangles represent stations with compiled temperature (Table 1). 
We note that the deuterium-temperature slope derived for the eastern part is higher than that previously established for East Antarctica by Lorius and Merlivat (1977) in the region from Dumont d'Urville to Dome C, in Terre Adélie $\left(6.04 \% / /{ }^{\circ} \mathrm{C}\right)$. This may arise for different reasons. First, the route from Dumont d'Urville to Dome $\mathrm{C}$ is far from the route from Vostok to Mirny; these routes are in Terre Adélie and Queen Mary Land, respectively, with a difference of $30-35^{\circ}$ longitude. Secondly, there may exist noticeable temperature differences (maybe up to $2^{\circ} \mathrm{C}$ ) between the meteorological records and the $10 \mathrm{~m}$ snow temperatures at some locations in this segment (Aver'yanov, 1964; Taylor, 1965).

Differences in comparison with data from Lorius and Merlivat tend to be observed only for those stations where the annual accumulation exceeds $20 \mathrm{~g} \mathrm{~cm}^{-2}$, i.e. when the data represent only a short period. Indeed, our regression line east of Vostok may be biased towards higher slope because of too high $\delta \mathrm{D}$ near the coast. For example, at Pionerskaya and station 102, our values are respectively 35 and $15 \%$ higher than those measured on previous samples from ice cores (Table 3).

More significant may be the fact that we use two different regression lines to describe the present data set east and west of Vostok. There is, for a given temperature, a systematic shift towards higher $\delta \mathrm{D}$ values to the west of Vostok (up to $40 \%$ ). This is an important finding for the interpretation of isotopic results obtained on deep ice cores drilled on the Antarctic Plateau (Vostok and Dome C). Due to the above-mentioned limitations inherent in our data set, we limit our attention to this point. New relevant and well-documented data are now being acquired that will shed light on this problem (paper in preparation by M. Stievenard and others).

This somewhat regional character of the relationship between stable isotopes and temperature is confirmed by examining the $\delta^{18} \mathrm{O}$ results. They show basic features quite similar to $\delta \mathrm{D}$ and will not be extensively discussed, but they have the advantage of making it possible to extend the comparison with previous data (a large part of

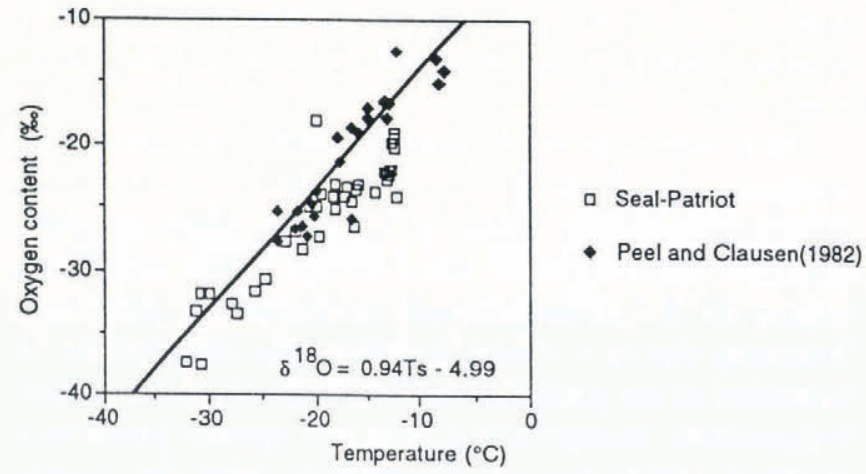

Fig. 7. Relationships between oxygen-18 and mean annual temperature for the Antarctic Peninsula. Open squares: for Seal Nunataks to Patriot Hills (this work); solid squares: data from Peel and Clausen (1982). The squared regression coefficient is 0.85 .

them being only analyzed for their $\delta^{18} \mathrm{O}$ ). This is true, in particular for the Antarctic Peninsula and the results from the Seal Nunataks to Patriot Hills, making possible a direct comparison with data previously obtained by Peel and Clausen (1982). The two data sets are plotted in Figure 7 and our values are in the same range as the previous data, in spite of their limited time span.

From Patriot Hills to Vostok (not shown), we get $\delta^{18} \mathrm{O}=0.77 T_{\mathrm{s}}-13.4$, in agreement with previous work in Marie Byrd Land (Craig, 1961b; Lorius and others, 1970) but not with that obtained at Eights Station (Epstein and Sharp, 1967) and Little America (Dansgaard and others, 1977). To the east of Vostok Station, the linear equation corresponds to: $\delta^{18} \mathrm{O}=0.90 T_{\mathrm{s}}-3.4$, showing a difference with respect to the west part, similar to that already observed for $\delta \mathrm{D}$. The results of GC30 (Qin Dahe and Wang Wenti, 1990), Dome C (Lorius and others, 1979), inland of Wilkes Land, (Young, 1979), Plateau Station and Pole of Relative Inaccessibility (Dansgaard and others, 1973), fit the regression line. The results for Law Dome (Budd and Morgan, 1977) and Victoria Land

Table 3. Comparison of mean $\delta D$ results from $1 \mathrm{~m}$ of snow with mean values from deeper ice sequences for several stations between South Pole and Mirny. The $\delta D$ result for station 102 is compared with the mean value obtained by P. Ciais and $V$. Lipenkov (unpublished) from a $150 \mathrm{~m}$ deep ice core close to this station

$\begin{array}{lllll}\text { South Pole } & -395.3 & -398.3 & -49.3 & \text { Jouzel and others, 1983 } \\ \text { Vostok } & -440.0 & -441.1 & -55.5 & \text { Petit and others, 1991 } \\ \text { Komsomolskaya } & -397.3 & -399.2 & -52.6 & \text { Petit and others, 1991 } \\ \text { Vostok-1 } & -356.8 & -344.2 & -47.1 & \text { Petit and others, 1991 } \\ \text { Pionerskaya } & -318.5 & -283.4 & -38.0 & \text { Petit and others, 1991 } \\ \text { Station 102 } & -247.0 & -229.6 & -27.7 & \end{array}$


(Lorius and others, 1970) do not fit this line very well, because these areas are near the coastline and Ross Sea, respectively.

Two important aspects must be taken into account in applying the Rayleigh isotopic model to Antarctic precipitation. First, there is a kinetic effect at snow formation as a result of the fact that vapor deposition occurs in a supersaturated environment over ice. Secondly, due to a strong inversion, the temperature of formation of the precipitation is different from the surface temperature. Incorporating these two aspects, Jouzel and Merlivat (1984) showed, for example, that the isotope surface-temperature slopes $\left(6.04 \% /{ }^{\circ} \mathrm{C}\right.$ for deuterium, and $0.75 \% /{ }^{\circ} \mathrm{C}$ for oxygen-18) may be explained in Terre Adélie (Dumont d'Urville-Dome C traverse). It may be that the different regression lines observed west and east of Vostok are due to a different relationship between condensation and surface temperatures or alternatively to different conditions in the oceanic regions providing these precipitations. The lack of meteorological data, in particular related to the strength of the inversion along the Trans-Antarctica route, prevents testing such ideas. These slopes are also in the same range as the values predicted by GCM simulations (Jouzel and others, 1987a; Joussaume and Jouzel, 1993) but these models also show one characteristic not captured by simple models, namely, that there is a significant dispersion of predicted values with respect to a linear relationship. This GCM feature is in clear agreement with the data presented in Figure 6.

\section{DEUTERIUM EXCESS}

Our data confirm that the geographic distribution of deuterium excess (d) in surface snow in Antarctica exhibits a well-defined pattern from the coast to the interior of the ice sheet, with relatively constant values at around $5 \%$ in coastal regions, steadily increasing inland, reaching a value of nearly 20\% in central East Antarctica (see Petit and others, 1991). This distribution may effectively be modeled using a simple Rayleigh model including kinetic effects provided that the temperature of evaporation at the oceanic origin of the air mass and the degree of supersaturation prevailing at snow formation are correctly chosen.

Figure $8 \mathrm{a}$ shows the relationship between the deuterium excess and the deuterium content in the $1 \mathrm{~m}$ surface snow along the traverse route; this presentation is chosen for the sake of comparison with the results of Petit and others (1991) shown in Figure 8b. In this graph, we see that the $d$ value is constant around $5 \%$ while $\delta \mathrm{D}$ values lie between $-150 \%$ and $-350 \%$ (the corresponding temperature range is from $-12^{\circ}$ to $45^{\circ} \mathrm{C}$ ). When the deuterium and the temperature drop below $-400 \%$ and $-50^{\circ} \mathrm{C}$, corresponding roughly to the region from the South Pole to Komsomolskaya, the $d$ value clearly shows the previously noted increase (Jouzel and Merlivat, 1984; Petit and others, 1991).

Our deuterium-excess results have to be considered as very preliminary, because there is only one measurement at each site and also because a significant measurement uncertainty $( \pm 1-2 \%)$ is attached to each value. These

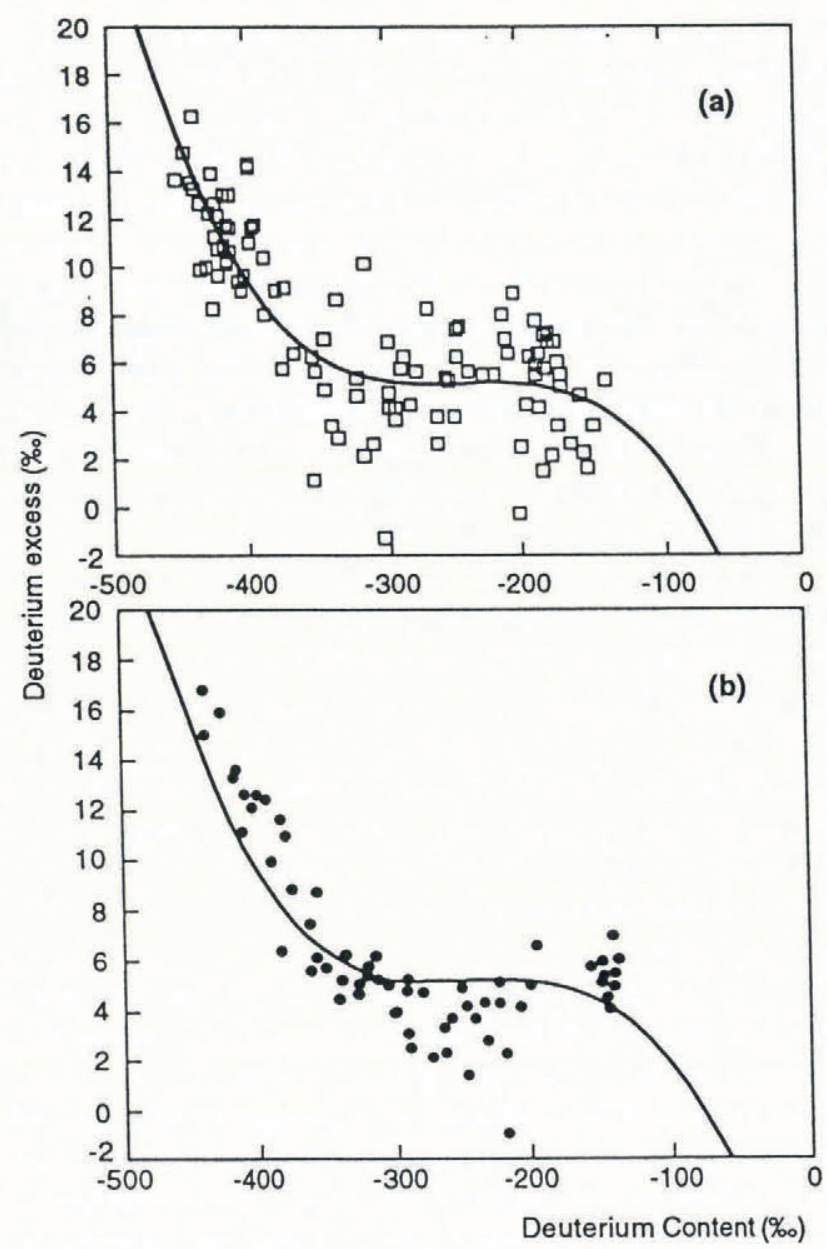

Fig. 8. Plots of the excess $d$ versus the deuterium content a. Along the Trans-Antarctica route with a three-order polynomial fitting $(d=-12.4-0.22 \delta D-8.99 \times$ $\left.10^{-4} \delta D^{2}-1.22 \times 10^{-6} \delta D^{3}\right)$. b. As compiled by Petit and others, (1991) with the same curve fitting.

two reasons possibly explain why there is much more scatter along the Trans-Antarctica route than for the data compiled by Petit and others (1991). Within these limits, the two data sets are remarkably consistent as illustrated by comparing Figure $8 \mathrm{a}$ and $\mathrm{b}$ (for the sake of this comparison, we have replotted the best-fit curve obtained along the Trans-Antarctica route on Figure $8 \mathrm{~b}$ ).

The main conclusions drawn by Petit and others (1991) may therefore be extended to the TransAntarctica route. According to these authors, the lower $d$ value $(5 \%)$ is interpreted as being associated with air masses originating not far from the coast, whereas the higher $d$ values are thought to correspond to all masses from the warmer ocean of the southern lower to midlatitude regions. There is indeed some evidence to support such an interpretation. Some of the samples which were collected during the Trans-Antarctica Expedition have been processed for chemical analyses. Several results, such as the sea salt and the methane-sulfonic acid (paper in preparation by Qin Dahe and others), independently suggest that the snow falling on the Antarctic Plateau is from a relatively warm ocean in the southern lower to mid-latitude regions.

One interesting approach would be to discover whether there is some correspondence between the change in the isotope temperature gradient, east and 
west of Vostok, and the spatial distribution of the deuterium excess, which could be expected if there was a link between this isotope gradient and differing characteristics of the regions where the precipitation originates. We await new and more accurate data along the Trans-Antarctica route to explore fully this promising research direction.

\section{CONCLUSIONS}

The relationship between $\delta \mathrm{D}$ and elevation shows two linear relations, one from Patriot Hills to Vostok and the other from Komsomolskaya to Mirny. In the segment from Vostok to Komsomolskaya, there is a continuous change in $\delta \mathrm{D}$ and $\delta^{18} \mathrm{O}$, although the altitude remains at about $3500 \mathrm{~m}$ a.s.l. throughout.

The difference in $\delta \mathrm{D}$ lines on the two sides of Vostok probably reflect different water sources or different fractionation processes. To confirm this result more evidence is needed, using meteorological observations, glacial chemistry studies or more accurate information on the deuterium-excess distribution.

Although the results concerning this last parameter must be considered as preliminary, they quite remarkably confirm the previously noted features of relatively constant values (around 5\%) for $\delta \mathrm{D}$ lower than $-350 \%$ and of a rapid increase when the elevation is over $3000 \mathrm{~m}$ a.s.l., especially in the core region of Antarctica, at the top of the Antarctic Plateau.

Finally, this study illustrates well the need for more work on the distribution of stable isotopes in Antarctica surface snow and warrants a co-ordinated international effort over the next few years to achieve a comprehensive coverage of the Antarctic continent. The study also shows the advantages of using a combination of isotopic models for data/model comparisons ranging from dynamically simple Rayleigh-type models to more complex threedimensional isotopic models.

\section{ACKNOWLEDGEMENTS}

This project was supported by the National Committee for Antarctica Research of China (NCAR of China), the National Committee of Science and Technology of China (NCST of China) and National Natural Science Foundations of China (NNSF of China). The other team members, W. Steger (U.S.A.), J.L. Etienne (France), V. Boyarski (U.S.S.R.), G. Somers (U.K.) and $\mathrm{K}$. Funatzu (Japan) were of great help during the field period. The staff of the offices of the 1990 International Trans-Antarctica Expedition and the Soviet Antarctic Expedition provided logistic support and transported the snow samples to Grenoble, France. We thank the French Atomic Energy Agency (CEA, Saclay) for isotopic measurements. We also thank Dr. E.J. Zeller and Dr. G. Dreschhoff for discussions and English corrections, as well as C. Genthon and R. Koster for providing Figures 4 and 5, P. Ciais and V. Lipenkov, for providing unpublished isotope data, and D. Fisher and an anonymous reviewer for their careful reviews.

\section{REFERENCES}

Aristarain, A.J., J. Jouzel and M. Pourchet. 1986. Past Antarctic Peninsula climate (1850-1980) deduced from an ice core isotope record. Climatic Change, 8(1), 68-89.

Aver'yanov, V.G. 1964. Temperature conditions of the snow cover in the interior regions of Antarctica. Sov. Antarct. Exped. Inf. Bull., 1, 2933.

Baerstchi, P. 1976. Absolute ${ }^{18} \mathrm{O}$ content of Standard Mean Ocean Water. Earth Planet. Sci. Lott., 31, 341-344.

Barkov, N. I. 1975. Snow accumulation along the Mirnyy-Vostok profile, 1970 through 1973. Antarct. J. U.S., 10(2), 56-57.

Budd, W. F. and V. I. Morgan. 1977. Isotope, climate and ice sheet dynamics from core studies on Law Dome, Antarctica. International Association of Hydrological Sciences Publication 118 (Symposium at Grenoble 1975-Isotopes and Impurities in Snow and Ice), 312-321.

Cameron, R. L., E. Picciotto, H. S. Kane and J. Gliozzi. 1968. Glaciology of Queen Maud Land traverse, 1964-1965. South Pole - Pole of Relative Inaccessibility. Ohio State Univ. Inst. Polar Stud. Rep. 23.

Craig, H. 1961a. Standard for reporting concentrations of deuterium and oxygen-18 in natural waters. Science, 133(3467), 1833-1834.

Craig, H. 1961b. Variations in meteoric waters. Science, 133(3465), 1702-1703.

Crary, A. P. 1963. Results of United States traverses in East Antarctica, 1958-1961. IG Y Glaciol. Rep. 7.

Dansgaard, W. 1964. Stable isotopes in precipitation. Tellus, 16(4), 436-468.

Dansgaard, W., S.J. Johnsen, H. B. Clausen and N. Gundestrup. 1973. Stable isotope glaciology. Medd. Grenl., 197(2).

Dansgaard, W., S.J. Johnsen, H. B. Clausen, C. U. Hammer and C. C. Langway, Jr. 1977. Stable isotope profile through the Ross Ice Shelf at Little America V, Antarctica. International Association of Hydrological Sciences Publication 118 (Symposium at Grenoble 1975Isotopes and Impurities in Snow and Ice), 322-325.

Dansgaard, W. and 6 others. 1982. A new Greenland deep ice core. Science, 218(4579), 1273-1277.

Dansgaard, W., J. W. C. White and S.J. Johnsen. 1989. The abrupt termination of the Younger Dryas climatic event. Nature, 339(6225), 532-534.

Drewry, D.J. 1983. The surface of the Antarctic ice sheet. In Drewry, D.J., ed. Antarctica: glaciological and geophysical folio. Cambridge, University of Cambridge. Scott Polar Research Institute, Sheet 2.

Epstein, S. and R.P. Sharp. 1967. Oxygen- and hydrogen-isotope variations in a firn core, Eights Station, western Antarctica. J. Geophys. Res., 72(22), 5595-5598.

Eriksson, E. 1965. Deuterium and oxygen-18 in precipitation and other natural waters. Some theoretical considerations. Tellus, 17(4), 498-512.

Fisher, D. A. 1990. A zonally-averaged stable-isotope model coupled to a regional variable-elevation stable-isotope model. Ann. Glaciol., 14, 65-71.

Fisher, D. A. and B. T. Alt. 1985. A global oxygen isotope model semi-empirical, zonally averaged. Ann. Glaciol., 7, 117-124.

Giovinetto, M.B. and C. Bull. 1987. Summary and analysis of surface mass balance compilations for Antarctica, 1960-1985. Ohio State Univ. Byrd Polar Res. Center. Rep. 1.

Gonfiantini, R., V. Togliatti, E. de Tongiorgi, W. de Breuck and E. Picciotto. 1963. Geographical variations of oxygen-18/oxygen-16 ratio in surface snow and ice from Queen Maud Land, Antarctica. Nature, 197(4872), 1096-1098.

Hagemann R., G. Nief and E. Roth. 1970. Absolute isotopic scale for deuterium analysis of natural waters. Absolute $\mathrm{D} / \mathrm{H}$ ratio for SMOW. Tellus, 22(6), 712-715.

Hamilton, W. L. and M.E. O'Kelley. 1971. Investigation of particulate matter in Antarctic firn. Antarct. Res. Ser., 16, 355-362.

Jacka, T.H., L. Christou and B.J. Cook. 1984. A data bank of mean monthly and annual surface temperatures for Antarctica, the Southern Ocean and South Pacific Ocean. ANARE Res. Notes 22.

Johnsen, S.J., W. Dansgaard, H. B. Clausen and C. C. Langway, Jr. 1972. Oxygen isotope profiles through the Antarctica and Greenland ice sheets. Nature, 235(5339), 429-434.

Johnsen, S.J., W. Dansgaard and J. W. C. White. 1989. The origin of Arctic precipitation under present and glacial conditions. Tellus, 41B, 452-468.

Joussaume S. and J. Jouzel. 1993. Paleoclimatic tracers: an investigation using an atmospheric general circulation model under ice age 
conditions. Part 2. Water isotopes. 7. Geophys. Res., 98(D2), 28072830.

Joussaume S., R. Sadourny and J. Jouzel. 1984. A general circulation model of water isotope cycles in the atmosphere. Nature, 311(5981), 24-29.

Jouzel, J. and L. Merlivat. 1984. Deuterium and oxygen 18 in precipitation: modeling of the isotopic effects during snow formation. F. Geophys. Res., 89(D7), 11,749-11,757.

Jouzel, J., L. Merlivat and C. Lorius. 1982. Deuterium excess in an East Antarctic ice core suggests higher relative humidity at the oceanic surface during the last glacial maximum. Nature, 299(5885), 688-691.

Jouzel, J., L. Merlivat, J.R. Petit and C. Lorius. 1983. Climatic information over the last century deduced from a detailed isotopic record in the South Pole snow. J. Geophys. Res., 88(C4), 2693-2703.

Jouzel, J., G. L. Russell, R. D. Koster, R.J. Suozzo, J. W. C. White and W.S. Broecker. 1987a. Simulations of the $\mathrm{HDO}$ and $\mathrm{H}_{2}{ }^{18} \mathrm{O}$ atmospheric cycles using the NASA GISS general circulation model: the seasonal cycle for present-day conditions. F. Geophys. Res., 92(D12), 14,739-14,760.

Jouzel, J. and 6 others. 1987b. Vostok ice core: a continuous isotopic temperature record over the last climatic cycle $(160,000$ years). Nature, 329(6138), 403-408.

Jouzel, J., R.D. Koster, R.J. Suozzo, G. L. Russell, J. W. C. White and W.S. Broecker. 1991. Simulations of the $\mathrm{HDO}$ and $\mathrm{H}_{2}{ }^{18} \mathrm{O}$ atmospheric cycles using the NASA GISS general circulation model: sensitivity experiments for present-day conditions. 7. Geophys. Res., 96(D4), 7495-7507.

Kato, K. 1977. Oxygen isotopic composition and gross $\beta$-radioactivity in firn. JARE Data Rep. Glaciol. 36, 158-169.

Koerner, R.M. 1979. Accumulation, ablation, and oxygen isotope variations on the Queen Elizabeth Islands ice caps, Canada. 7. Glaciol., 22(86), 25-41.

Kotlyakov, V.M., K. S. Losev and L. A. Loseva. 1977. Ledovoy balans Antarktidy [The ice budget of Antarctica]. Izv. Akad. Nauk SSSR, Ser. Geogr., 1, 5-15.

Lipenkov, V.Ya. 1980. Nekotoryye osobennosti nakopleniya snega na profile Mirnyy-Vostok [Features of snow accumulation at the Mirnyy-Vostok profile]. Inf. Byull. Sov. Antarkt. Eksped. 100, 59-65.

Lorius, C. and L. Merlivat. 1977. Distribution of mean surface stable isotope values in East Antarctica: observed changes with depth in the coastal area. International Association of Hydrological Sciences Publication 118 (Symposium at Grenoble 1975-Isotopes and Impurities in Snow and Ice), 127-137.

Lorius, G., L. Merlivat and R. Hagemann. 1972. Fluctuation of the average deuterium content of precipitation in Antarctica. Sov. Antarct. Exped. Inf. Bull., 7(6), 1970, 513-516.

Lorius, C., L. Merlivat, J. Jouzel and M. Pourchet. 1979. A 30,000-yr isotope climatic record from Antarctic ice. Nature, 280(5724), $644-648$.
Lorius, C. and 6 others. 1985. A 150,000 year climatic record from Antarctic ice. Nature, 316(6029), 591-596.

Merlivat, L. and J. Jouzel. 1979. Global climatic interpretation of the deuterium-oxygen 18 relationship for precipitation. F. Geophys. Res., 84(C8), 5029-5033.

Peel, D. A. and H.B. Clausen. 1982. Oxygen-isotope and total betaradioactivity measurements on $10 \mathrm{~m}$ ice cores from the Antarctic Peninsula. J. Glaciol., 28(98), 43-54.

Peel, D. A., R. Mulvaney and B. M. Davison. 1988. Stable-isotope/airtemperature relationships in ice cores from Dolleman Island and the Palmer Land Plateau, Antarctic Peninsula. Ann. Glaciol., 10, 130-136.

Petit, J. R., J. Jouzel, M. Pourchet and L. Merlivat. 1982. A detailed study of snow accumulation and stable isotope content in Dome C (Antarctica). F. Geophys. Res., 87(C6), 4301-4308.

Petit, J.R., J.W.C. White, N.W. Young, J. Jouzel and Ye.S. Korotkevich. 1991. Deuterium excess in recent Antarctic snow. 7. Geophys. Res., 96(D3), 5113-5122.

Picciotto, E. E. 1967. Geochemical investigations of snow and firn samples from East Antarctica. Antarct. F. U.S., 2(6), 236-240.

Qin Dahe and Ren Jiawen. 1991. A study on snow profile and surface characteristics along a $6000 \mathrm{~km}$ trans-Antarctica route, (I). Part 1. Science in China (Series B), 34(9), 100-108.

Qin Dahe and Wang Wenti. 1990. The historical climatic records in ice core from the surface layer of Wilkes Land, Antarctica. Science in China (Series B), 33(4), 460-466.

Robin, G.de Q 1983. The climatic record from ice cores. In Robin, $\mathrm{G}$. de $Q$, ed. The climatic record in polar ice sheets. Cambridge, etc., Cambridge University Press, 180-195.

Rozanski, K., C. Sonntag and K. O. Münnich. 1982. Factors controlling stable isotope composition of European precipitation. Tellus, 34(2), 142-150.

Schwerdtfeger, W. 1970. The climate of the Antarctic. In Orvig, S., ed. Climates of the polar regions. Amsterdam, etc., Elsevier, 253-355. (World Survey of Climatology, 14.)

Schwerdtfeger, W. 1975. The effect of the Antarctic Peninsula on the temperature regime of the Weddell Sea. Mon. Weather Rev., 103(1), 45-51.

Shimizu, H. 1964. Glaciological studies in West Antarctica, 1960-1962. Antarct. Res. Ser., 2, 37-64.

Taylor, L.D. 1965. Glaciological studies on the South Pole traverse, 1962-1963. Ohio State Univ. Inst. Polar Stud. Rep. 17.

Young, N. W. 1979. Measured velocities of interior East Antarctica and the state of mass balance within the I.A.G.P. area. F. Glaciol., 24(90), 77-87.

The accuracy of references in the text and in this list is the responsibility of the authors, to whom queries should be addressed. 